\title{
Parent Involvement in Children Reading Development
}

\author{
Didik Suryadi ${ }^{{ }^{*}}$, Yufiarti $^{2}$ and Tuti Nuriah Erwin ${ }^{3}$ \\ ${ }^{1}$ Universitas Bengkulu, Departement of Education, JI.WR.Supratman Kota Bemgkulu, Indonesia \\ ${ }^{2}$ Unversitas Negeri Jakarta, Graduate School, Indonesia \\ ${ }^{3}$ Universitas Negeri Jakarta, Indonesia
}

Received 02 Dec 2017, Accepted 03 Feb 2018, Available online 10 Feb 2018, Vol.6 (Jan/Feb 2018 issue)

\begin{abstract}
The research was aimed to develop home reading programs for parent to tutor the children learn to read at home. The development procedure owed the work of Borg and Gall's research and development model. Tryout and implementation were conducted in a Kindergarten School in Bogor, Indonesia. The data was collected through observation, interview and checklist. The product was considerably feasible referred to the judgments of five experienced kindergarten teachers, three early childhood education and 15 parents participating in the implementation. It was concluded that the model contributed to overcome the problem encountered by both parents and kindergarten teachers in how to help children learn to read at home.
\end{abstract}

Keywords: Parent's involvement, kindergarten reading program, research and development

\section{Introduction}

Reading competency is one of the vital competencies that children should achieve for their success in school and in their life. That is like a belief that countries, communities, schools and parents have to pursue for children. Most parents interviewed in this preliminary study were encouraged as they viewed that elementary school teachers prefer welcome to a student who has a better reading skill. Some parents then took their children to a private institution outside of school offering a reading, writing and arithmetic training for 3-5 age children. The rest are disadvantaged from being able to take their children to such an institution. The parents then put a high expectation to the kindergarten school in preparing the children to be ready to enter an elementary school. Kindergarten teachers shared the same concern with the parents. Realizing that the school time was limited to 2,5 hours a day, the teachers turned to insist the parent share responsibility of helping the children learn to read at home.

The teacher viewed however that the parents had not worked optimally in helping their children learn to read at home. It was similar to the fact Edward portrayed

*Corresponding author Didik Suryadi (ORCID ID: 0000-0003-1819-0845) received The Master Degree in Early Childhood and Elementary Education from The University of lowa, lowa City, The USA in 1995. He works as a lecturer at the Department of Education, Universitas Bengkulu, Bengkulu, Indonesia, Yufiarti is a Professor of Psychology, lecturer of Early Childhood Education, Universitas Negeri Jakarta, Indonesia. Tuti Nuriah Erwin is Emeritus professor at Universitas Negeri Jakarta, DOI: https://doi.org/10.14741/ijmcr.v6i01.10918 teachers' perspective in his research. Children reading difficulties came from parents who had not done anything to prepare the children for school, who did not care if their children read or not (Edwards in Morrow.1995:58 59). Observation taken early in this research find dat the kindergarten school has provided the parents with a like communication book purposed as a media to encourage the parent more actively participate in tutoring their children learn to read at home. The book functioned as a "communication bridge" between the school and the parents. However, it consisted of very limited information about what the parents should do that made it inadequate as a media for supporting the parents to teach children learn to read at home.

Those made parents do not play their role optimally. On the other hand, parents have vital role in helping children learn to read. (Bedrova \&Leong,1999, Blasi \& Klark,2005, Arnold,et.al,2008;Kirby \& Hogan. 2008). Although the parents were motivated and their role in supporting children reading development were clearly important, It was likely that parents have few ideas about how to provide such a help (Danielson,1997:74). Therefore, it will be beneficial when educators or schools provide families or parents with specific strategies to support children's literacy skills, (Blasi and Klark, 2005:46)

It is clear that both parents and school or kindergarten teachers shared the same problem relating to the improving parents' involvement in children's' reading development. Parents have a little knowledge and 120 |Int. J. of Multidisciplinary and Current research, Vol.6 (Jan/Feb 2018) 
practice in how to help children's reading development. The kindergarten teachers or school provided very limited source that help parent tutor the children optimally. This is the concern of this research set from.

\section{Research question}

The research question comes from the understanding that parents involvement was vital in helping children learn to read. On the other hand, parents have a little idea in how they could participate in helping their children learn to read. Still on other that the 'communication book" aimed to build the parent's involvement was inadequate for its purpose.

The main question of the research was how to develop a parent involvement model facilitating the parents in helping the kindergarteners learn to read at home. That led the parents to function as a home kindergarten reading tutor.

\section{Literature Review}

\subsection{Parents Participation Program}

This research took much beneficial from the understanding of some projects relating to parents involvement in helping children learn to read undertaken at home. Namely, PCHP, Parent Child Home Program that focus on empowering parent-child verbal interaction, supporting reading and play activities in the home, building language and literacy-reach home environments, and providing children with the language, early literacy, and social-emotional skills they needed to enter school, ready to be successful students. HIPPY, Home Instruction for Parents of Preschool Youngsters was the family project aimed to empower parents to actively prepare their children for success in school. Parents are provided with a set of developed curriculum, books and materials designed to strengthen their children's cognitive skills, early literacy skills, social/emotional and physical development. HIPPY is a curriculum exposes skills, concepts, and experiences with book to prepare young children ready to school. RIF, Reading Is Fundamental is another is another example of family program run under the recognition that parents and other family members played a special role in encouraging children to read (Grave,Wendorf in Morrow,1995:130). In 1992, the RIF designed The Family of Readers program that sent books directly to children to support motivational reading activities. It also included the guidance and the means to the parents to plan and run such a program to their children (Grave,Wendorf in Morrow,1995:136). PAT, Parent as Teacher, is another family involvement program running in a smaller scale. Winter and Roose (1999:384) described that the PAT project provided information and guidance to helps parents prepare for the adjustment of having a new baby in the home. PAT also involved specially trained educators in home visit to provide information on child development, practical to foster growth and learning, and effective ways to deal with difficult situations. The PAT project promoted group meeting where parents could share experience, common concern, frustrations and success. B.E.A.R (Be Excited About Reading) was another family project created by teachers at Howard Early Childhood Center, San Antonio, Texas. The teachers planned and arranged children reading books that the children would bring home The teacher reported the positive result of the project. The children and parents showed enthusiasm in reading and related activities.

Other school scale family improvement program was named WRAP, Family Writing and Reading Appreciation Program. The program was designed to promote interest in reading and writing activities, through which the children were expected to be motivated in reading and writing activities, (Morrow, et.all in Morro,1995:74\}. The WRAP was a literature based, in which the school provided each student with five to eight books in a various genre in the book center in a classroom that every student was allowed to check them out. Morrow reported the success of the program. Parents became more self confident about being able to help the children.

\subsection{Reading Element}

Reading ability is an ability that cannot be grabbed in one night. It comes from the long process and involved interrelated structuring abilities. Unlike speaking that accomplished naturally, reading is a competency that needs to be learned. Reading is like a building construction that consists of some forming structures Achieving reading ability therefore is like constructing a building that needs to possess some capabilities of the constructing elements.

Experts identify elements involved in reading process. Adams (1990:51-55) described basic skills that a child should obtains. One of them is awareness of spoken language comprising of some smaller components, since reading is assumedly based on oral language. Different from understanding spoken language that child doesn't need to pay attention to the smaller units of the language, a child in reading needs to pay their attention to the units. The most accessible unit of spoken language is word. Words are then considered as the fundamental units of that children need to comprehend. For the purpose of reading, a child needs to understand that speech comprises some words. This leads to the view of reading as word identification or decoding process. Although it is not the ultimate goal of reading, decoding competency is required as a developing part of literacy development (Cooper,1993:299). The next important element of spoken language that children should aware is phoneme as a word is formed by a chain of phonemes. Reading in alphabetic language is set up that makes learners come to know the phonemes. Early reading instruction therefore should ease learners to understand 
that a word comprises of phonemes. The second awareness that Adam (1990:61-62) identified as an important ability is awareness about print, since reading involves print comprehension. It is fundamental then that children comes to awareness that words are speakable. As children understand that a word consists of some phonemes, the children need to aware that a word consists of chained letters. Dodge, Colker and Heramon \{2002:126) identified 7 elements of literacy that children need to hold as successful reader. Those elements are increased vocabularies, phonological awareness, knowledge about print, letters and words, comprehension, book and other text understanding lead to literacy as enjoying resources. The first four belongs to the basic skills of reading ability. Wood and McLemore (2001:1) identified two major elements needed for children to develop their reading ability. Those are knowledge about letter and teaching phonic. NRP, National Reading Panel identified 5 important elements that has major contribution to reading ability. Children need to have abilities in phonemic awareness, phonic, fluency, vocabulary, and text comprehension. Konza viewed elements that involve in achieving reading ability as spoken language, phonology awareness, vocabulary, fluency, and comprehension. The Department of Education of California (2008:78-85) resumed important elements to develop reading ability for preschool children. Children need to have knowledge of print concept, phonological awareness, alphabetic and words/print recognition, comprehension and analysis of age-appropriate text, and literacy interest consisting of interest in book, listening to stories. Those elements of reading are considered to be the content of reading element in this research.

\subsection{Teaching Approach}

\subsubsection{Phonics approach}

There are two main approaches in teaching reading that have seemed to battle for period of time. Those are phonic approach in one hand and non phonic approach on the other. The oldest approach in teaching reading however is phonic approach. Phonic is teaching method stressing on the relationship between sound and symbol (Harris, Hodges:1995). The importance of phonic approach in teaching early reading refers to the present of alphabetic language system, included the Indonesian language. The critical point in the alphabetic language system is that oral language linearly transcribes to writing system in which it consists of many sound by sound, phoneme by phoneme correspondences. This alphabetic principle enables all words can be transcribed and decoded (Bowey,2006:81). Research and literature reviews has shown the importance of phonic approach in teaching early reading. It is known from the meta-analysis that teaching reading using systematic phonic program resulted better reading outcome than those using non phonic program. Systematic approach had also a positive effect on spelling in kindergarteners and first graders (Saskia de Graf, et.all ,2009:320). National Reading Panel reported that systematic phonics instruction significantly makes bigger contribution to children's growth in reading than alternative program providing unsystematic or no phonics instruction. The Panel also reported that the phonic approach has the biggest impact when implemented in kindergarten or first grade than in upper grade. (NRP,2000:2.92-2.93). Torgeson, Brook and Hall reported their research finding that systematic phonics instruction was found to have a statistically significant positive effect on reading accuracy. The research also reported that there was no significant differences in terms of reading accuracy between normally developed children and for at risk children when teaching with systematic phonics instruction. There were no evidences in term of superiority over one to the other between synthetic and analytic phonics instruction (Torgeson, Brook and Hall, 2008).

It is summarized that kindergarteners will take more benefit from the implementation of explicit systematic approach in reading instruction. There is no significantly differences in superiority whether kindergarteners learn to read in analytical or in synthetic teaching approach. Considering the findings then this research applied the phonic approach as the basis of designing parents' activity in helping children learn to read. This application took a consideration that Bahasa Indonesia is an alphabetic language system.

\subsubsection{Read aloud}

This research was aimed to develop programs for parent in helping children learn not only to read but also to enjoy reading. The phonic approach convinces from which children take benefit in learning reading skill. For the purpose of teaching children to enjoy reading, this research approached with reading aloud activities. Cooper (1993:35-36) has identified some benefits of reading aloud activity. Read aloud is a motivating element. Read aloud delivers a message to children about reading as excitement activity. Children learning to read on their own generally have had an adult reading to them frequently. Read aloud is also convinced as the most influencing factor to the success of learning reading (Routman,1994:32). There is no better way than reading aloud to make children interested in book (Norton,1993:431). Swanson, et.al (2011:271) reported their finding about the impact of read aloud among at risk student with reading difficulties. Through the MetaAnalysis method Swanson confirmed reading aloud contributions to some literacy areas. Read aloud revealed significantly positive effect to children's language, phonological awareness, print concepts, comprehension and vocabulary outcomes. At risk students experiencing read aloud achieved higher literacy outcomes than those who do not take part in a such activity. From their 
literatures review, Lane and Wright informed some advantages of read aloud practice (Lane and Wright,2007:668-669). Read aloud could increase children's vocabulary. It can promote children's syntactic development, variety of skill and abilities related to emergent literacy. Read aloud could increase children's ability to recognize words.

It is obvious that read aloud is essential. It contributes significantly to all areas of children's literacy. Reading aloud is a single most important activity for building the knowledge for successful reading (Morison, Wlodarczyk, 2009:111). This research took the read aloud activities as a part of the designed reading program.

\section{Research Method}

\subsection{Approach and procedure}

The research applied procedure of research and development approach comprising of three main steps taken from the knowledge of Borg and Gall's research and development model. Those are preliminary, design and implementation. The following figure describes the research steps undertaken to find the product that consist of program that the parents apply in helping their children learn to read at home.

Need assessment was to collect information whether or not the model was needed. Need assessment consisted of analysis of factual conditions the parents and the school encounter relating to what the parents' participation in supporting the school to help the children learn to read at home. The research got knowledge from the literature research about essential elements of early reading and corresponding activities the parent would do to help the children learn to read at home. The next step was drafting the product consisting of designing the content and activities and the physical performance of the product. Prior to the try out, the products were sent to five experience kindergarten teachers and three experts in early childhood education to get a review about the feasibility of the draft. Two try out procedures were done involving five parents in three days. A small and deep discussions with the parents participated followed each of the try out. The small deep discussion brought about some idea to revise the product prior to the implementation of the model. Fifteen parents excluded those had been taking part in the try out were involved in the implementation of the model. It took seven weeks of implementation procedure. The first step of the implementation was socialization of the model to the participating parents from which the participants got the knowledge of why and how the program would be implemented. Each parent during the implementation got one "READING BAG" consisting of one packet of reading activity the parent would undertake at home. The parent were allowed to keep the bag for one week then returned and exchange it with one other pack on the following week.. One parent was asked for help to coordinate the exchange the bag management. The next step was evaluation to decide the feasibility of the final product. The evaluation procedure were involved the parents participating in the implementation. Plan of the mass production was not in the scope of the research but rather as an idea that might be undertaken in the future. Five kindergarten teachers each whom has 3, 9, 10, 12, 14 years teaching experience and three experts in early childhood education were asked for their judgment of the feasibility of the product. The judgment value was represented in the score of product aspects formulated in four options Likert Scale. The criteria was that if the main score was the same or higher than $75 \%$ then the mode was considered feasible.

\subsection{Data Collection}

Three types of data were collected in this research. The first was data collected in the need assessment process. The data was collected through observation and interview. Observation was done to get a view of what the school has done relating to parent participation in helping children learn to read at home. Interview was done to a teacher and to the targets who are the parents whose children learn in the school. The second data consisted of statements lists in the model of four Likert Scale by which the teacher, experts put their evaluation in scoring system categorized in four condition, very poor, poor, good, very good. These were done to decide the feasibility of the product. The third data was from parents taking part in the implementation process. The data was about the parents' views of their experiences in dealing with helping their children learn to read at home.

\section{Findings}

\subsection{Product}

As stated earlier that the main question of the research was how to develop a parent participation mode facilitating the parents in helping the kindergarteners learn to read. The research procedures followed has come to the result of the physical product that constituted the model. The parents implemented the product to support their children learn to read. The followings are the characteristic of the product. It consists of 7 packets of learning activities. Each packet consists of 2 types of learning activities. First type is activity relating to reading aloud to real commercial story books. The research provided 22 commercial story books during the implementation session. The second is relating to learning reading basic skills. It has been designed 7 books by which the parents help their children learn essential components of reading at home and 7 exercise reading books specifically designed for the children to exercise learning to read independently relating to the reading skill that has been learned. Each pack of book is provided with 2 picture word cards, 1 pack of 5 or 10 picture vocal 
letter cards, 1 pack of 5 to 10 consonant letter cards and 1 pack of 15 to 20 syllable cards. All of the materials then were put in one bag named as "THE READING BAG". There are seven "READING BAG" that each of which the children brought to their parents and exchange to the next pack every Thursdays.

\subsection{Feasibility}

The kindergarten teachers and experts judgments strongly convince that the product is feasible to be implemented as the parent participation model in developing kindergarten early reading ability. The following figure is the distribution scores of the judgment.

Table 1: Judgment Score of the Model

\begin{tabular}{|c|c|c|c|c|c|c|}
\hline Judger & \multicolumn{5}{|c|}{ score } & Mean \\
\hline $\begin{array}{c}\text { Kindergarten } \\
\text { Teacher }\end{array}$ & 92,8 & 85,7 & 82,1 & 89,3 & 89,3 & 87,8 \\
\hline Expert & 92,5 & 87,5 & 87,5 & 89,17 \\
\hline Parents ( $\mathrm{n}=15)$ & \multicolumn{7}{|c|}{86,30} \\
\hline
\end{tabular}

\section{Discussion}

\subsection{General result}

The general result of the research convinced that the product through which the parents participated in supporting children learn to read at home was considerably feasible.

\subsection{Read aloud}

One of the most significant improvement was the children's attitude toward reading activities. All the parents reported that their children were very enthusiastic of reading and being read to. That was very different from the situation before the model implemented in which the children rare did have such experiences. From the interview some parents informed that the children were involved when the parents read a book to them, by probing about some aspect of the story. As an example, the child asked "is that really true that the cafe can fulfill the human plead ? ". Some parents informed that their children asked for being read to the same book more than twice during one week implementation session, and also informed that the children asked for keeping the books for their own. The interview also found the information that the children frequently asked about vocabulary. That was a strong indication that the children have a potential of good motivation to read that needs to be cultivated by the family and the school. The model was then like a channel that brought the potential to grow.

\subsection{Learn basic skills}

The 7 series of book designed were purposed to facilitate parents help children to learn elements of reading ability.
They were accompanied with picture words, syllables and letters. The parent viewed that those were very useful for them when they supported their children to learn the skills. They also informed that the first session in the book help them to help the children recognize the sound in a word. They felt that they got an alternative way to blend or to analyze sound in a word or syllable. They used to do by first naming letters and then combine them into syllables and word. The parents described that the books accompanied with picture cards provided more structured activities that ease them to help the children learn to read. The cards and the special designed exercise reading books performed in color pictures made the children more involved in learning reading. The parents gave a high appreciation to the material used for the cards which were made from glossy photo papers. The performance of the reading materials were attracted the children and the parents that make the interaction between parent and children during the process learning reading at home became more enjoying and motivating.

\section{Conclusion}

It strongly convinces that the model was faceable. When the parents used the model in tutoring their child, they seemed to be the second reading teacher who teach reading to the kindergarten at home. It was also indicated from the interviews with the parents that the model brought about enjoying and motivating reading activities both for parents and children. Finally, the model provided an alternative solution for the parents who need the information and practical ways to help their children learn to read at home. On the other side, the kindergarten school and teachers could take advantage of the model in the need of encouraging parents' participation in helping children learn to read at home.

The limitation of the model was on the limited content of reading skills carried out in the model in which it was limited to teach very simple, CV-CV (Consonant Vocal-Consonant-Vocal) combination structure of phonemes in a syllable. It is suggested to the kindergarten teachers or school to willingly crate a like model with more complex phonemes combination, such as CV-CVC.

\section{Acknowledgment}

The authors put a great honor to the kindergarten principal and teachers who were willing to give input for the project. The authors also appreciate the parents who participated in this research.

\section{References}

[1] Adam, Marilyn Jagers, 1990, Beginning to Read: Thinking And Learning About Print, Urbana, University of Ilinois at Urbana-Champign.

[2] Arnold, David H, et.al, 2008, Parent Involvement in Preschool: Predictors and the Relation of Involvement to 
Pre literacy Development, School Psychology Review, Vol.37.No.1

[3] Bedrova,Elena; Leong; Paynter, 1999, Redefining Liteacy, Educational Leadership, Vol.57.No.2

[4] Blasi, Mary Jane, Clark, 2005, For Parents Particularly: Family as Educators: Supporting Literacy Development, Childhood Education, Vol.82.No.1

[5] Bowey, Judit.A, 2006, Need for Systematic Syntetic Phonics Teaching Within the Early Reading Curicullum, Autralian Psychologist, Vol.41.No.2

[6] Cooper, David,1993, Literacy Helping Children Construct Meaning, Boston, Houghton Mifflin Company.

[7] Danilson, Kathy Evans, 1997, Improving Parental Involvment in Children's Literacy, Reading Horizon, Vol.37.No.4

[8] Degraf, Saskia, et.all , 2009, Benefits of Systematic Phonics Instruction, Scientific of Reading, Vol.13.No.4

[9] Dodge, Diana Trister, Colker, Heramon, 2002, The Creative Curriculum for Pre School, Washington, Teaching Strategies.

[10] Edward, Patric,1995," Combining Parents' and Teachers' Storybook Reading at Home and School" in Family Literacy Connection in School and Communities, Lesley Mandel Morro, The International Reading Association.

[11] Harris, Theodore, Richard Hodges,, 1995, The Literacy Dictionary, Delaware, International Reading Association

[12] Kirby, John R, Brenda Hogan,2008, Family Literacy Environment and Early Literacy Development, Exceptionality Education Canada, Vol.18.No.3

[13] Konza, ELizabet B , Copeland, Understanding the Reading Process, Research into Practice, Government of South Australia.
[14] Lane, Holly B; Wright, 2007, Maximizing the effectiveness of Reading Aloud, The Reading Teacher, Vol.60.No.7

[15] Morrison, Vanessa; Wlodarzyk, 2009, Revisiting ReadAloud: Instructional Strategies That Encourage Students' Engagement With Texts, The Reading Teacher, Vol.63.No.2

[16] National Reading Panel. 2000. Teaching Children To Read An Evidence-Bsed Assessment of the Scientific Research Literature on Reading and Its Implications for Reading Instruction.

[17] Norton, Dona E, 1989, The Effective Teaching of Language Arts, New York, Macmillan Publishing Company

[18] Routman, Regie, 1994, Invitation Changing as Teachers and Learners $K-12$, Portsmouth, Heinemman

[19] Sugiyono, 2014, Metode Penelitian Kuantitatif Kualitatif dan $R \& D$, Bandung, Alfabeta.

[20] Swanson, et.all, 2011, A Synthesis of Read-Aloud Interventions on Early Reading Outcomes Among Preschool Through Third Graders at Risk for Reading Difficulties, Journal of Learning Disabilities,

[21] Torgeson, Carole; Brooks;Halll, 2008, Systematic Review of the Research Literature on the Use of Phonics in the Teaching of Reading and Spelling, Research Report, No.711

[22] Winter, Mildred, Rose, 1990, Fostering Intergenerational Literacy : The Missouri parents as Teacher Program, The Reading Teacher, February

[23] Wood, Janice, McLemore, 2001, Critical Component in Early Literacy-Knowledge of Letters of The Alphabet and Phonics Instructions, The Florida Reading Quarterly, Vol.32.No.2 